\title{
Over grenzen: beheersing van horizontale interne en externe relaties
}

\author{
Prof. Dr. J. van der Meer-Kooistra
}

\section{Inleiding}

Management accounting-/control-systemen zijn vooral gericht op verticale relaties binnen organisaties. Deze systemen en technieken staan ten dienste van de leidinggevenden, die daarmee het doen en laten van de mensen lager in de organisatie kunnen aansturen en beheersen. Budgetteringssystemen, standaardkostensystemen, prestatiemeetsystemen, beloningssystemen, ze gaan allemaal uit van het perspectief van de verticaal gestructureerde organisatie. Prestatie-indicatoren als ROI, RI, ROA, enzovoort, maar ook nieuwe prestatie-indicatoren als EVA (Economic Value Added), CFROI (Cash Flow Return on Investment) of shareholder value zijn beheersingsinstrumenten voor de centrale leiding om gedecentraliseerde organisatiestructuren (organisaties waarbinnen divisies en/of business units worden onderscheiden) te kunnen sturen en beheersen. Decentralisatie van de besluitvorming naar een lager niveau om redenen van overschrijding van de verwerkingscapaciteit van de centrale leiding tast het principe van de centrale besluitvorming, waarop het verticale organisatiemodel berust, niet aan. Deze vorm van decentralisatie is alleen een verlegging van de centrale besluitvorming naar een lager niveau en werkt gezagsnivellerend (Groffen, 1963).

Galbraith heeft er in zijn boek Designing Complex Organisations van 1973 al op gewezen dat verticale organisatiestructuren met verticale besluitvormingsstructuren niet toereikend zijn voor complexe organisaties. Complexe organisa-

Prof. Dr. J. van der Meer-Kooistra is verbonden aan de faculteit Bedrijfskunde van de Rijksuniversiteit Groningen als hoogleraar Financieel Management. ties zullen andere structuren en middelen moeten gebruiken om adequaat op ontwikkelingen in de omgeving te kunnen reageren. Zo ziet Galbraith de inrichting van laterale verbanden als een van de mogelijkheden. Het verticale organisatieperspectief gaat uit van hiërarchische lagen en het bestaan van machtsverschillen tussen mensen en is gebaseerd op taakinstructie, controle en disciplinaire maatregelen. Laterale verbanden zijn relaties tussen gelijken waartussen in principe geen machtsverschillen bestaan. Omdat de traditionele management accounting-/controlsystemen en -technieken uitgaan van het verticale organisatieperspectief en derhalve van het bestaan van machtsverschillen, zijn deze niet geschikt voor het besturen van laterale verbanden die berusten op gelijkheid.

Naast het ontstaan van laterale of horizontale verbanden binnen de hiërarchie zien we ook steeds vaker laterale verbanden ontstaan tussen onafhankelijke organisaties. Verschillende typen van structurele samenwerkingsverbanden kunnen worden onderscheiden. Zo zien we uitbestedingsrelaties ontstaan, waarbinnen transacties van voor de uitbesteder essentiële goederen en diensten plaatsvinden. Ook zien we dat organisaties nieuwe ondernemingen oprichten, waarin gezamenlijke activiteiten worden ontplooid. Deze joint ventures worden door de moederbedrijven gezamenlijk aangestuurd. Voorts besluiten ondernemingen, vanwege de omvangrijke investeringen en daaraan verbonden risico's, tot het gezamenlijk opzetten van $\mathrm{R} \& \mathrm{D}$-activiteiten. Bovendien kan zo essentiële kennis voor het ontwikkelen van nieuwe technologieën worden samengevoegd. Deze gezamenlijke activiteiten tussen gelijkwaardige organisaties vragen om andere aansturings- en beheersingsinstrumenten 
dan die door de traditionele management controlsystemen kunnen worden geboden (zie ook:

Hopwood, 1996; Otley, 1994). Dit komt omdat er in principe sprake is van gelijkwaardigheid van de samenwerkende partijen en omdat de belangrijkste elementen van een succesvolle samenwerking andere zijn dan de elementen die coördinatie binnen een hiërarchische relatie kenmerken.

In deze bijdrage wordt onderzocht welke elementen kenmerkend zijn voor horizontale samenwerking tussen gelijkwaardige partijen, hetzij binnen organisaties en derhalve de grenzen van organisatieonderdelen overschrijdend, hetzij tussen organisaties en derhalve over de grenzen van organisaties heen. De onderzoeksvraag is gericht op het vaststellen van de eisen die aan management accounting-/control-systemen (in het vervolg aan te duiden met MACS) worden gesteld, willen deze systemen horizontale samenwerkingsverbanden kunnen sturen en beheersen. Het is uitdrukkelijk niet de bedoeling om in dit artikel nieuwe MACS te ontwerpen die geschikt zijn voor het beheersen van horizontale relaties. Het onderzoek hiernaar staat nog in de kinderschoenen (Hopwood, 1996; Otley, 1994; Shields, 1997). In de uitwerking ligt de nadruk op horizontale relaties. Binnen organisaties zullen naast horizontale relaties altijd verticale verbanden bestaan. Dit betekent dat bij het ontwerpen van MACS hiermee rekening moet worden gehouden.

Deze bijdrage is als volgt opgebouwd. In paragraaf 2 wordt nagegaan waarom laterale of horizontale relaties ontstaan. Vervolgens worden in paragraaf 3 de belangrijkste verschillen tussen verticale en horizontale organisatiestructuren besproken. Aan de hand van twee praktijkvoorbeelden van horizontale relaties, de ene intern en de andere extern, worden in paragraaf $4 \mathrm{de}$ belangrijkste elementen van horizontale samenwerkingsverbanden onderzocht. In paragraaf 5 worden de essentiële kenmerken van horizontale relaties beschreven. In paragraaf 6 ten slotte wordt nagegaan aan welke eisen MACS moeten voldoen om horizontale relaties te kunnen sturen en beheersen. Tevens worden enkele theoretische concepten besproken die kunnen worden gebruikt voor het ontwikkelen van MACS voor horizontale relaties. De bijdrage wordt afgesloten met enkele conclusies en met het bespreken van de richting van verder onderzoek.

\section{Waarom ontstaan horizontale relaties?}

Laterale verbanden en plattere organisatiestructuren ontstaan volgens Galbraith (1973) als reactie op toenemende onzekerheid. Ook Otley (1994) ziet toenemende onzekerheid ten gevolge van groeiende wereldwijde concurrentie als een belangrijke factor voor het complexer worden van de beheersing van organisaties. Daarnaast doen ook technologische ontwikkelingen de onzekerheid toenemen. Dankzij nieuwe technologieën kunnen producten meer en andere functies vervullen, zijn andere productieprocessen mogelijk en ontstaan geheel nieuwe producten en diensten. Snellere veranderingen in producten en productietechnieken, kortere levensduur van producten, omvangrijke investeringen voor het ontwikkelen van nieuwe producten en productieprocessen, waardoor de risico's enorm toenemen, maken dat ondernemingen voortdurend aandacht moeten schenken aan het aanpassen van hun activiteiten aan nieuwe omstandigheden. Om op voortdurende veranderingen te kunnen reageren worden ondernemingen gedwongen flexibel te zijn. Deze flexibiliteit kan worden bereikt door de voortdurende veranderingsprocessen in te bedden in de normale operationele activiteiten. Dit maakt het noodzakelijk om zo veel mogelijk mensen in de onderneming actief bij de veranderingsprocessen te betrekken en deze processen niet alleen over te laten aan de leidinggevenden. Daarvoor moeten de mensen initiatieven kunnen nemen en ruimte hebben voor creativiteit. Pascale e.a. (1997) spreken in dit verband van 'revitalization or transformation' van de organisatie. Mensen moeten van mening zijn dat zij de prestaties van de organisatie kunnen beïnvloeden. Dit kan volgens Pascale e.a. worden bereikt door eenieder ruimte voor initiatief te geven, door conflicten niet uit de weg te gaan, en door niet alleen betrokkenheid te creëren bij de eigen eenheid maar ook bij de organisatie als geheel.

Door toenemende complexiteit is kennis en ervaring op steeds meer verschillende gebieden nodig. We zien dan ook dat het ontwikkelen van nieuwe producten en productieprocessen steeds vaker het werk is van teams, waarin mensen zijn opgenomen van verschillende bedrijfsonderdelen. Essentieel is dat binnen deze teams tot uitwisseling van kennis en ervaring wordt gekomen. 
Voorwaarde hiervoor is dat de teamleden op voet van gelijkheid met elkaar omgaan. De teamprestaties worden in gezamenlijkheid bereikt en zijn niet toe te wijzen aan individuen.

De hiervoor beschreven ontwikkelingen sluiten goed aan bij het groeiende individualisme en bij de toename van kennis en kunde dankzij steeds verdergaande opleiding en scholing van mensen. Mensen in organisaties willen worden aangesproken op hun kennis en kunde en willen zich kunnen ontplooien. Om hieraan tegemoet te komen zijn organisaties gedwongen taken te verruimen en mensen ruimte te geven voor het nemen van initiatieven en voor het zelfstandig kunnen functioneren. In dit verband wordt gesproken over 'empowerment' van mensen op alle niveaus, in het bijzonder op dat van de werkvloer. Deze vorm van decentralisatie, die gericht is op het bevorderen van initiatief en zelfstandigheid. gaat uit van organisaties die mensen meer als gelijken behandelen. en berust in veel mindere mate op machitsverschillen. Dit type decentralisatie werkt volgens Groffen (1963) gezagverplaatsend.

Toename van de complexiteit word ook als belangrijkste oorzaak gezien van het ontstaan van samenwerkingsverbanden tussen organisaties. Door samen te werken krijgen organisaties toegang tot bronnen waarover zij zelf niet beschikken (Håkansson en Johanson, 1988; Johanson en Mattson, 1987; Easton, 1989). Hierdoor kunnen schaal- en/of scopevoordelen worden bereikt en kunnen organisaties flexibeler functioneren (Martin, 1997). Samenwerkingsverbanden kunnen gemakkelijker worden aangegaan en ontbonden dan wanneer organisaties zelf de desbetreffende activiteiten zouden moeten opzetten c.q. afstoten.

\section{Verschillen tussen verticale en horizontale organisatiestructuren}

Traditionele organisatiestructuren zijn verticaal ingericht. Deze verticale structuren berusten op hiërarchische relaties tussen mensen: de leidinggevenden beslissen en de onder hen geplaatsten voeren de beslissingen uit. Verticale structuren zijn opgebouwd uit verticale relaties. Verticale structuren en relaties berusten op:

1 machtsverschillen ontleend aan de hiërarchie;

2 bevoegdheid tot het nemen van beslissingen en het geven van opdrachten bij de leidinggevenden;
3 uitvoering van opdrachten door de nietleidinggevenden;

4 toezicht door de leidinggevenden op de juiste en tijdige uitvoering van de opdrachten;

5 mogelijkheid van het nemen van disciplinaire maatregelen door leidinggevenden om de nietleidinggevenden bereid te vinden de opdrachten uit te voeren.

Plattere organisatiestructuren worden in de organisatieliteratuur al veel langer beschreven. Een voorbeeld is het in 1963 verschenen proefschrift van Groffen met de titel 'Horizontaal organiseren'. Hij schrijft dat 'op het ogenblik een ontverticalisering in de organisatie van een aantal bedrijven merkbaar is' (p. 1). Hij onderzoekt waarom ontverticalisering ontstaat, wat de gevolgen hiervan zijn en op welke wijze integratie van het geheel en de juiste sturing kan worden verkregen. Hij zoekı naar nieuwe organisatiemiddelen met een meer horizontaal karakter, d.i. niet berustend op machtsverschillen. Volgens hem gaat de verticale organisatie uit van de persoonlijkheidseigenschap gehoorzaamheid, en veronderstelt ontverticalisering de bereidheid tot zakelijke schikking met gelijken. Ontverticalisering veronderstelt meer zelfstandigheid van mensen. Ook Groffen ziet ontverticalisering ontstaan als reactie op toenemende complexiteit.

Horizontale organisaties hebben volgens Groffen de volgende twee kenmerken. Allereerst zijn deze organisaties gegrond op gelijkheid tussen de partijen. Dit houdt in dat machtsverschillen ontbreken, waardoor organisatiemiddelen als opdrachten en disciplinaire maatregelen niet kunnen worden ingezet. In plaats van een opdrachtrelatie is er sprake van een overlegrelatie tussen de partijen. Bij de gezamenlijke besluitvorming dienen partijen rekening te houden met elkaars gegevens en met de gevolgen van de beslissing voor eenieder. Een tweede kenmerk van een horizontale organisatie is dat er twee soorten beslissingsgebieden kunnen worden onderscheiden: een gemeenschappelijk beslissingsgebied waar alle partijen via overleg tot beslissingen komen, en een individueel beslissingsgebied waar iedere partij zelfstandig beslissingen neemt. Daarbij moet wel rekening worden gehouden met de invloed op het gemeenschappelijke beslissingsgebied, waardoor er sprake is van relatieve zelfstandigheid. Groffen (1963, p. 83) heeft de horizontale organisatievorm uitgewerkt 


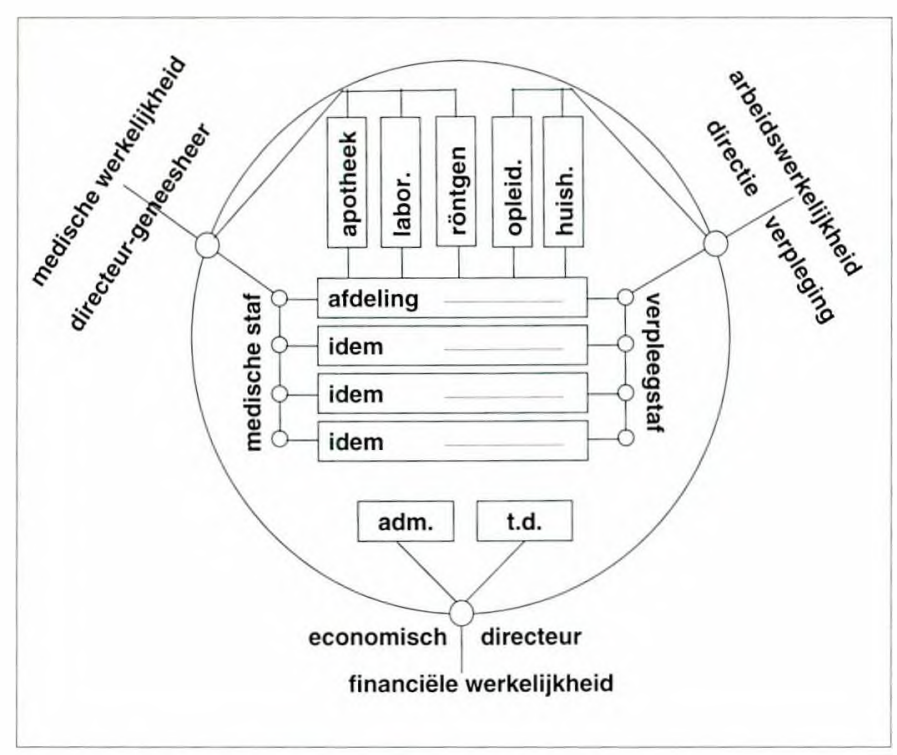

Figuur 1: Horizontale organisatiestructuur

voor een ziekenhuis zoals is weergegeven in figuur 1 .

Het denkmodel dat in figuur 1 is aangegeven (niet aan de orde is of dit model een reële afspiegeling is van de praktijk van vandaag de dag), berust op de noodzaak van samenwerking tussen de drie partijen in een ziekenhuis: medische staf, verpleegstaf en economisch-technische staf. Een belangrijk deel van de activiteiten van een ziekenhuis komt tot stand in nauwe samenwerking tussen deze drie partijen. Daarvoor is inbreng van kennis en ervaring van alle partijen vereist. Een ander deel van de activiteiten wordt uitgevoerd door de partijen apart. Hierover kunnen de partijen afzonderlijk beslissen.

Ook Thompson (1967) en Mintzberg (1983) wijzen erop dat wederzijdse afstemming centraal staat in de cirkelstructuur. Dit in tegenstelling tot de wielstructuur, die gekenmerkt wordt door de informatieverwerkende en coördinerende rol van een centraal persoon. Uit onderzoek blijkt dat de wielstructuur geschikt is voor eenvoudige taken, terwijl de cirkelstructuur zich beter leent voor het uitvoeren van complexe taken (Leavitt, 1951).

Horizontale relaties tussen zelfstandige organisaties ontstaan om uiteenlopende redenen: samenbrengen van kennis, concentreren op kernactiviteiten en uitbesteden van niet-kernactiviteiten, delen van risico's, toegang tot linancieringsbronnen, slechten van entreebarrières enzovoort. De vorm waarin deze relaties worden gegoten, zijn zeer divers. In het geval van een joint venture richten twee of meer zelfstandige ondernemingen een nieuwe onderneming op. Samenwerking kan ook contractueel worden geregeld zonder dat er sprake is van een nieuwe onderneming. Als het om samenwerking gaat tussen een opdrachtgevende partij en verschillende uitvoerende ondernemingen, zijn verschillende vormen mogelijk. Zo kan de opdrachtgevende partij met iedere uitvoerende partij een afzonderlijke overeenkomst sluiten. Het is ook mogelijk de afzonderlijke contracten aan te vullen met een overkoepelend alliantiecontract, waarbij zowel de opdrachtgevende partij als de uitvoerende partijen deel uitmaken van de alliantie. Een andere mogelijkheid is dat één van de uitvoerende partijen als hoofdcontractor wordt aangewezen, die belast wordt met het organiseren van de inzet van de subcontractors. Ook kan de opdrachtgevende partij samenwerking aangaan met een consortium bestaande uit de uitvoerende partijen. De keuze voor de contractvorm hangt nauw samen met de aard van de werkzaamheden.

Niet alleen aan de voorkant van de onderneming maar ook aan de achterkant zien we steeds meer grensoverschrijdende horizontale relaties ontstaan met belangrijke afnemersgroepen. Bijvoorbeeld: producenten van consumentenproducten die speciale relaties aangaan met retailorganisaties om in gezamenlijk overleg activiteiten te ontplooien om de logistieke kosten te verminderen.

Het concept van de waardeketen (zie o.a. Porter, 1985; Shank en Govindarajan. 1993) is gericht op de relaties tussen de verschillende productieve stappen in de keten van grondstoffen tot finale consumptie of gebruik. inclusief de afvalverwerking. Talrijke onathankelijke organisaties kunnen deel uitmaken van deze waardeketen. Sommige organisaties kunnen de gehele waardeketen of een belangrijk deel ervan omvatten, terwijl andere organisaties zich specialiseren op een bepaalde stap in de keten. Gespecialiseerde organisaties kunnen zich toegang verschaffen tot de gehele waardeketen door het vormen van netwerken met organisaties die zich richten op voorafgaande en volgende productieve stappen. De waardeketengedachte past in de open-systeemtheorie (zie o.a. Katz en Kahn, 1978). Deze theorie gaat ervan uit dat er sprake is van aanpassing en beïnvloeding tussen individu, organisatie en omgeving. Op het grensvlak tussen individu/ 
groep en organisatie en het grensvlak tussen organisatie en omgeving dienen de problemen van stabiliteit versus flexibiliteit en aanpassing versus beïnvloeding te worden opgelost. Hopwood (1996) constateert dat er in de praktijk steeds meer aandacht wordt besteed aan integratie van activiteiten tussen netwerken van ondernemingen. Kortom, de aandacht voor het grensvlak onderneming en ongeving neemt toe.

Ook voor deze ondernemingsgrenzenoverschrijdende relaties geldt, dat het in principe relaties betreft ussen gelijkwaardige partijen die in samenwerking met elkaar activiteiten uitvoeren. De partijen zijn in zekere mate athankelijk van elkaar en zullen daarom rekening dienen te houden met elkaars belangen. Inzicht in deze belangen is daarvoor belangrijk. Om de activitejten goed te kunnen uitvoeren is voorts informatie over elkaars omstandigheden noodzakelijk. Tussen de partijen bestaat een contractuele relatie. De partijen zijn gehouden aan de afspraken die in het contract zijn vastgelegd. Op grond hiervan kan een partij sancties nemen als de andere partij de afspraken niet nakomt. Relaties tussen onathankelijke partijen zijn dan wel gebaseerd op gelijkwaardigheid, dat neemt niet weg dat er verschillen in onderhandelingspositie tussen de partijen kan bestaan. Partijen kunnen hier rekening mee houden, hetgeen in het uiterste geval ertoe kan leiden dat de relatie niet wordt aangegaan.

\section{Voorbcelden van horizontale relaties}

Aan de hand van de beschrijving van een tweetal praktijkvoorbeelden van horizontale rclaties worden de belangrijkste kenmerken onderzocht van dergelijke relaties. Hierna wordt zowel aandacht geschonken aan een praktijkvoorbeeld van een interne horizontale relatie als een prakiijkvoorbeeld van een externe horizontale relatie beschreven. Voor een uitvoerige beschrijving van beide praktijkvoorbeelden wordı verwezen naar Van Helden e.a.. 1999, respectievelijk Van der Meer-Kooistra en Vosselman, 1999.

\subsection{Interne horizontale relatie}

Hoogovens Staal produceert en verkoopt wereldwijd diverse staalproducten. In 1995 is de functionele organisatiestructuur gewijzigd in een

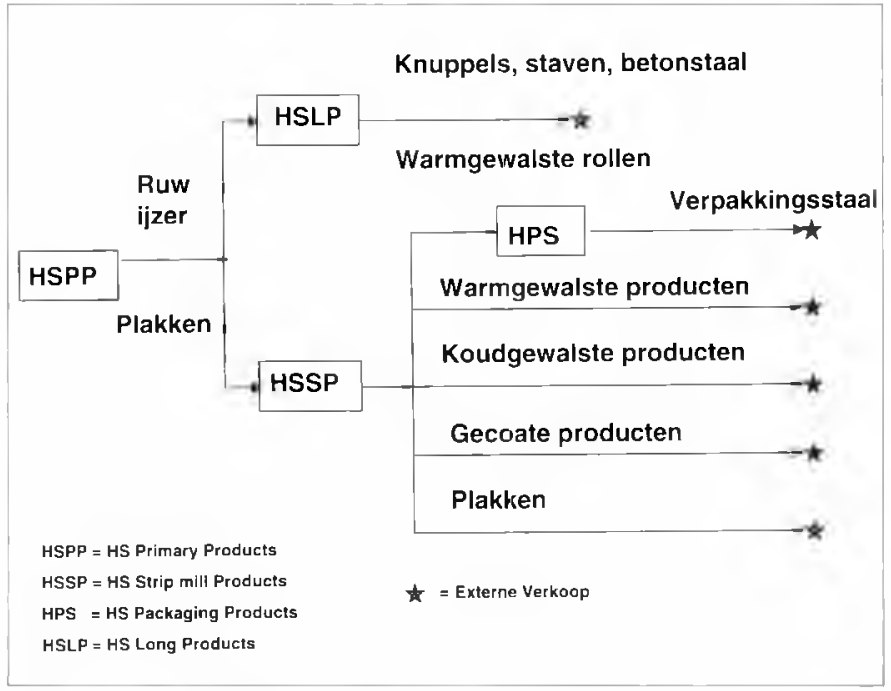

Figun 2: Het staalproces

business unit-structuur. Belangrijkste aanleiding voor deze wijziging was een verandering van de markt. Op de markt neemt de diversiteit aan marktpartijen toe, die hun eigen eisen stellen ten aanzien van soort, kwaliteit en vernieuwing van producten. ledere business unit beweegt zich op een bepaald deel van de staalmarkt en onderhoudt direct contact met de eigen afnemersgroepen. Voorheen werd het contact met de diverse afnemersgroepen door de centrale verkoopafdeling onderhouden, hetgeen met hel toenemen van de diversiteit tot minder goede afstemming met de afnemers leidde. Ondanks de opdeling van de organisatie in voor het eigen resultaat verantwoordelijke business units, bestaan er nauwe technische en capaciteitsrelaties tussen de business units. Dil komt omdat de business units ieder een deel van het productieproces voor hun rekening nemen. Hierdoor bestaan er omvangrijke stromen van tussenproducten tussen de verschillende business units. Figuur 2 geeft een overzicht van de interne transacties tussen de verschillende business units.

Het opknippen van de organisatie heeft geleid tot eenheden met eigen bevoegdheden en verantwoordelijkheden. Het begrotings- en budgetteringssysteem en het prestatiemeetsysteem sluiten hierop aan. Vanwege de omvangrijke onderlinge transacties hanteert Hoogovens Staal een transfer pricing-systeem. Dit systeem wordt in belangrijke mate centraal ingevuld: interne transacties zijn verplicht en de verrekenprijs is van hogerhand vastgesteld. De gehanteerde MACS zijn vooral gericht op de verticale relaties. 
Omdat er evenwel nauwe relaties bestaan tussen de business units, is er naast sturing en beheersing van de verticale relaties ook behoefte aan onderlinge afstemming, dus sturing en beheersing van de horizontale relaties. Lawrence en Lorsch (1967) spreken van de noodzaak van integratieve mechanismen die het gedifferentieerde systeem bij elkaar moeten houden. Deze mechanismen moeten ervoor zorgen dat de productieprocessen en de productiecapaciteit in de verschillende stappen goed op elkaar worden afgestemd, en dat rekening wordt gehouden met gewenste productkwaliteiten en leveringstijdstippen. Ook veranderingen op de afzetmarkten, bijvoorbeeld nieuwe producten of andere productkenmerken of nieuwe afnemers, hebben consequenties voor de achtereenvolgende productiestappen en vragen derhalve om nauwe onderlinge afstemming tussen de business units. Ook de eerste stap in het staalproces waar de business unit HSPP verantwoordelijk voor is, zal zich rekenschap dienen te geven van de ontwikkelingen op de diverse markten. Deze onderlinge afstemming zal vooral door de business units moeten gebeuren, omdat de mensen in de business units over de relevante informatie beschikken.

De onderlinge afstemming tussen de business units is met name gericht op de volgende aspecten:

- technische afstemming: aansluiting van productieprocessen en productietechnieken;

- afstemming van capaciteiten: er is deels sprake van gemeenschappelijke capaciteit die ingezet kan worden voor verschillende producten;

- bezetting van capaciteit: vanwege de kapitaalintensiteit is een goede bezetting van de verschillende productieprocessen sterk bepalend voor de winstgevendheid van Hoogovens Staal;

omvang onderlinge productstromen: omdat de onderlinge productstromen zeer omvangrijk zijn, kunnen deze stromen niet via de markt worden gekocht of verkocht;

- afstemming van productiestappen: deze afstemming betreft de aspecten kwaliteit, hoeveelheid en tijd;

- afstemming op marktontwikkelingen: omdat er vaak sprake is van langdurige leveringsverplichtingen is voor de afstemming op marktontwikkelingen een langetermijnperspectief vereist:
- blootstelling aan marktrisico's: alle business units zullen zich rekenschap moeten geven van de marktrisico's, die met name worden veroorzaakt doordat de staalmarkt sterk cyclisch is waardoor prijzen sterk kunnen schommelen; en doordat aan de producten steeds nieuwe eisen worden gesteld en er regelmatig nieuwe producten op de markt worden gebracht.

\subsection{Externe horizontale relatie}

De Nederlandse Aardolie Maatschappij (NAM) is een olie- en gasproductiebedrijf. De kernactiviteiten omvatten de exploratie en productie van gas en olie. De overige activiteiten, zoals het boren van de gaten en het onderhoud van de productielocaties en platforms, worden grotendeels uitbesteed. Het grootste gasveld van de NAM is gelegen in Noordoost Groningen. De winning van het gas uit dit veld vindt plaats via 29 productielocaties of clusters. Deze clusters zijn in de jaren zestig aangelegd volgens de techniek die toendertijd beschikbaar was. Enkele jaren geleden is besloten om deze clusters te renoveren en tevens te voorzien van compressoren om zo de gasdruk op te voeren, die door de jarenlange winning is teruggelopen. De renovatie en de installatie van compressoren behoren niet tot de kernactiviteiten van de NAM. Daarom is besloten tot uitbesteding van dit renovatie- en installatieproject. Tegelijkertijd is besloten om ook het onderhoud van de gerenoveerde clusters uit te besteden en dit onderhoudsproject te beschouwen als samenhangend met het renovatieproject. Voor het gehele project, het Groningen Long Term Project (GLT-project) genaamd, is één offerte uitgebracht. Met het GLT-project is een bedrag gemoeid van ongeveer 4,5 miljard gulden: 3,5 miljard gulden voor de renovatie en installatie van compressoren en 1 miljard gulden voor het onderhoud. Dit uitbestedingsproject wordt gekenmerkt door (1) de geïntegreerde benadering, dat wil zeggen dat de NAM een contract afsluit met één partij in plaats van met alle afzonderlijke partijen, en door (2) het uitbesteden van niet alleen de uitvoering maar ook van het management/de coördinatie van de werkzaamheden.

De totale opdracht, die een looptijd heeft van 25 jaar waarvan 10 jaar voor de renovatie, is uitbesteed aan een consortium van vijf bedrijven. 
De uitbesteding heeft twee en een half jaar geduurd en is geschied volgens de Europese regels voor tenderen. Het consortium is gekozen op grond van door de NAM opgestelde beoordelingscriteria. De vijf bedrijven zijn gespecialiseerd in het uitvoeren van de vijf hoofdfuncties van het project.

Met het consortium zijn twee contracten afgesloten, een voor de renovatie en de installatie van compressoren en de ander voor het onderhoud. Beide contracten zijn raamcontracten met opties. Zo voorziet het renovatiecontract in een opdracht voor het renoveren van 11 clusters en een optie voor het renoveren van de overige 18 clusters. De precieze uitwerking van de contracten geschiedt via werkorders. In 1997 is met de uitvoering van de werkzaamheden begonnen.

De belangrijkste kenmerken van de relatie van de NAM met het consortium zijn:

- zeer lange duur: 25 jaar is zeer uitzonderlijk; omdat het contract opties bevat, kan de NAM de relatie evenwel tussentijds verbreken;

- hoog contracthedrag: bij de selectie heeft de NAM mede gekeken naar de mate van afhankelijkheid van de consortiumleden van dit contract; een te grote afhankelijkheid werd door de NAM niet wenselijk gevonden;

- flexibiliteit: door te kiezen voor een raamcontract en de nadere opdrachten via werkorders uit te geven is de NAM in staat om tussentijds veranderingen aan te brengen in de aard van de opdrachten; het toepassen van opties verhoogt bovendien de flexibiliteit voor de NAM;

- optreden van leereffecten: omdat ieder jaar een beperkt aantal clusters wordt gerenoveerd en de renovatiewerkzaamheden voor alle clusters dezelfde zijn, wordt verwacht dat aanzienlijke leereffecten zullen optreden, hetgeen zich zal vertalen in steeds lagere renovatiekosten; bovendien raken de partijen steeds beter op elkaar ingespeeld, hetgeen zowel geldt voor de relatie NAM-consortium, als voor de relatie tussen de consortiumleden;

- toegang tot specifieke kennis van de consortitumleden: voor de kwaliteit van de uitvoering van de werkzaamheden is de NAM afhankelijk van de kennis en ervaring van de consortiumleden; de NAM beschikt zelf nauwelijks over deze kennis en ervaring;

- investeren in relatie: alle contractpartijen investeren in de relatie en raken, naarmate de tijd voortschrijdt, steeds meer op elkaar aangewezen; als de NAM tussentijds zou besluiten om de relatie te verbreken zal de NAM opnieuw een uitbestedingsprocedure moeten opstarten en opnieuw een relatie moeten opbouwen.

\section{Essentiële kenmerken van horizontale relaties}

Nu ik twee praktijkvoorbeelden van horizontale relaties heb beschreven en de belangrijkste kenmerken ervan heb aangegeven, kan ik conclusies trekken over de kenmerken waarop de sturing en beheersing van dit type relaties zich zullen moeten richten. Voordat ik daartoe overga, wil ik er met nadruk op wijzen dat binnen ondernemingen zowel verticale als horizontale relaties voorkomen. Ondernemingen zullen altijd gekenmerkt worden door enige mate van hiërarchie. MACS zullen zich moeten richten op beide soorten relaties. Traditionele MACS, zoals begrotings- en budgetteringssystemen, responsibility accounting, traditionele prestatiemeetsystemen, transfer pricing-systemen enzovoort, sluiten vooral aan bij de verticale structurur. Participatie en consultatie van mensen lager in de hiërarchie bij begroting- en budgetrondes en bij het meten en beoordelen van prestaties veranderen deze verticale gerichtheid niet. Dit geldt in principe ook voor transfer pricing-systemen, waarmee immers wordt beoogd om de grenzen tussen de organisatieonderdelen scherp te trekken. Die systemen echter, die ruimte laten voor de interne partijen om in onderling overleg de interne transacties op elkaar af te stemmen, gaan wel uit van het primaat van de horizontale relatie. Relaties tussen onafhankelijke ondernemingen zijn niet onderhevig aan de hiërarchie. Het gaat hierbij om gelijkwaardige partijen die niet aan elkaar ondergeschikt zijn. Wel kan de onderhandelingspositie tussen de partijen verschillen, waardoor een van de partijen de transactievoorwaarden in belangrijke mate zou kunnen bë̈nvloeden. De andere partij heeft altijd de mogelijkheid af te zien van de relatie. Voor relaties binnen de onderneming is dit niet het geval.

De hiervoor beschreven horizontale relaties betreffen complexe activiteiten die vragen om nauwe onderlinge afstemming tussen alle partijen. Er is sprake van gemeenschappelijke beslissingsgebieden waar de partijen in nauw overleg tot besluiten moeten komen. Daarnaast 
kunnen beslissingsgebieden worden onderschejden waar iedere partij voor zich beslissingen neemt. Zo onderhoudt iedere business unit van Hoogovens Staal contacten met zijn eigen afnemersgroepen. De eisen die door de verschillende afnemersgroepen aan de producten worden gesteld (omvang, kwaliteit, leveringstijd enzovoort) moeten vervolgens worden afgestemd met de overige business units, omdat hier consequenties uit voortvloeien voor de wijze van produceren en voor de bezetting van de productiecapaciteit. Bij het GLT-project is ieder consortiumlid verantwoordelijk voor zijn eigen inbreng, maar moet deze inbreng wel worden afgestemd met de inbreng van de overige partijen. Ook in de tijd gezien is er sprake van afstemming. De aard van de renovatie beïnvloedt de wijze waarop het onderhoud van de clusters wordt uitgevoerd.

Voor de onderlinge afstemming is regelmatig persoonlijk overleg noodzakelijk. Tijdens dit overleg moet uitwisseling van ieders kennis en ervaring plaatsvinden. Het is essentieel dat iedere partij in staat is om zijn kennis en ervaring in te brengen en dat aandacht wordt besteed aan de raakvlakken tussen de kennis en ervaring van iedere partij. Persoonlijk overleg is noodzakelijk omdat alleen op deze manier zogenaamde 'tacit knowledge', persoonsgebonden kennis, kan worden uitgewisseld. De kennis en ervaring die kan worden beschreven, kan via schriftelijke procedures worden uitgewisseld.

Omdat het complexe activiteiten betreft, is het noodzakelijk dat iedere partij voortdurend inzicht heeft in de gerealiseerde en in de geplande activiteiten (gewerkte uren, werkelijke kosten, geproduceerde producten, uitval, kwaliteiten, omvang orders, leveringstijden, inzet van personeel, enzovoort). Uitwisseling van informatie hierover is een voorwaarde voor goede samenwerking.

De inspanningen van alle partijen bepalen in onderlinge samenhang de resultaten. Daarom is er sprake van gemeenschappelijk bereikte resultaten. Dit maakt het lastig om de resultaten aan iedere partij afzonderlijk toe te wijzen. Dit zorgt ervoor dat er bij Hoogovens Staal een spanningsveld is tussen enerzijds het bestaan van nauwe relaties tussen de business units, terwijl anderzijds de business units verantwoordelijk worden gehouden voor ieders eigen resultaat. leders eigen resultaat wordt mede bepaald door de inspanningen van de andere business units. Het najagen van alleen het eigen belang zonder rekening te houden met het belang van de andere business units zal het resultaat van Hoogovens Staal als geheel negatief beïnvloeden. Ook een deel van de resultaten van het GLT-project is toe te schrijven aan de samenwerking tussen de verschillende partijen.

In beide praktijkvoorbeelden zijn leereffecten waar te nemen. Bij Hoogovens Staal zullen de business units gezamenlijk moeten leren hoe om te gaan met nieuwe vragen en eisen van de afnemers. Ook zal men gezamenlijk moeten reageren op nieuwe technologische ontwikkelingen. Bij het GLT-project zullen de partijen leren van de renovatie van het eerste cluster. Er is door de NAM een periode van een jaar ingebouwd voor het uitvoerig evalueren van de renovatie van dit cluster. Ook daarna zullen de partijen blijven leren van de renovatie van de volgende clusters. De NAM heeft voor de bepaling van het contractbedrag rekening gehouden met de financiële consequenties van deze leereffecten.

In beide praktijkvoorbeelden is er sprake van onzekerheid met betrekking tot toekomstige ontwikkelingen op de markten en in technologie. In beide gevallen moet het mogelijk zijn om te reageren op niet voorziene veranderingen. In geval van het GLT-project betekent dit dat het contract met het consortium niet volledig kan zijn en dat daardoor tussentijds herzieningen kunnen worden verwacht. Deze herzieningen worden onder meer via werkorders en via nieuwe afspraken over de wijze van beloning uitgewerkt. Deze tussentijdse aanpassingen maken blootstelling aan opportunistisch gedrag van een van de partijen mogelijk. Daarom is het belangrijk dat alle partijen belang hebben bij continuïteit van het contract en negatieve effecten zullen ondervinden van stopzetting van de relatie.

Doordat de inbreng van alle partijen van belang is en de partijen afhankelijk zijn van elkaars kennis en ervaring is het streven naar 'cement' tussen de partijen zeer belangrijk. Een goede onderlinge verstandhouding en het rekeninghouden met ieders belangen zijn daarvoor vereist. Dit vraagt om vertrouwen tussen de partijen. Niet alleen is het van belang dat partijen beschikken over de vereiste kennis en ervaring, dus vertrouwen hebben in elkaars competentie, ook is het noodzakelijk dat partijen kunnen vertrouwen op elkaars woord (contractueel vertrouwen). Daarnaast is de ontwikkeling van 
goodwill-vertrouwen (Sako, 1992) vereist, dat wil zeggen dat partijen bereid zijn rekening te houden met elkaars belangen en eventueel nadeel accepteren ten gunste van de totale uitkomsten. Kortom, de partijen in een langdurige horizontale relatie moeten bereid zijn te investeren in de relatie. Zij accepteren daarmee dat de onderlinge afhankelijkheid groeit naarmate de tijd voortschrijdt. Zonder goodwill-vertrouwen is een langdurige nauwe relatie, die onderhevig is aan onzekerheid, volgens Sako niet mogelijk.

\section{Eisen aan de besturing en beheersing van horizontale relaties}

De essentiële kenmerken van horizontale relaties zoals die hiervoor zijn beschreven, vinden hun grondslag in de kern van deze relaties, te weten nauwe samenwerking tussen in principe gelijkwaardige partijen. Daarom is er sprake van gemeenschappelijke beslissingsgebieden en van gemeenschappelijke resultaten. Daarom is er de noodzaak van persoonlijk overleg en regelmatige uitwisseling van informatie. Daarom is er sprake van al doende leren en de wenselijkheid van flexibiliteit in de relatie. Daarom ook is een goede onderlinge verstandhouding en vertrouwen tussen de partijen van groot belang. Het besturen en beheersen van horizontale relaties zal zich moeten richten op deze essentiële kenmerken.

MACS zullen rekening moeten houden met het bestaan van gemeenschappelijke beslissingsgebieden en gemeenschappelijke resultaten. Dit betekent dat de traditionele scheiding tussen organisatieonderdelen minder relevant wordt. Budgetteringssystemen worden doorgaans ingericht volgens deze traditionele scheiding. Marginson (1999) heeft onderzoek verricht naar de wijze waarop de activiteiten worden beheerst in een onderneming waarin veel activiteiten worden verricht door projectteams, die bestaan uit mensen van verschillende business units en van verschillende niveaus. Hij stelt vast dat de inrichting van verantwoordelijkheidscentra met de aanwijzing van verantwoordelijke managers en het daarbij aansluitende budgetteringssysteem nauwelijks wordt gebruikt voor de beheersing van de horizontale relaties in deze onderneming. Hij constateert dat het sociale beheersingssysteem, dat gericht is op het creëren van vertrouwen, samenwerking en wederzijdse verantwoordelijk- heid, een centrale rol speelt bij de beheersing van de activiteiten. MACS zullen zodanig moeten worden ingericht dat ze deze mensen motiveren tot het leveren van gezamenlijke inspanningen. ongeacht in welk organisatieonderdeel mensen zijn ondergebracht. De bereidheid tot samenwerking en het in staat zijn samen te werken staan centraal. Voor het meten hiervan zullen andere prestatiemeetsystemen moeten worden opgezet dan de traditionele systemen, die gericht zijn op de prestaties van eenieder afzonderlijk of op de prestaties van aparte organisatieonderdelen. Scott en Tiessen (1999) komen tot de conclusie dat het meten en beoordelen van teamprestaties een specifieke aanpak verdient. De teamleden zullen betrokken moeten zijn bij de opstelling van de normen en de prestaties zullen breed en in samenhang gemeten moeten worden. Voorts zullen de teamprestaties een substantieel deel moeten uitmaken van de beloningsgrondslag.

Informatiesystemen moeten worden opgezet met informatie over de verrichte activiteiten, ingezette middelen en geplande activiteiten en middelen, die voor alle partijen op ieder moment toegankelijk zijn. Met de komst van geïntegreerde informatiesystemen waarmee informatie naar alleriei gezichtspunten kan worden uitgesplitst en voor alle niveaus toegankelijk is, kan worden voorkomen dat partijen verschillend geïnformeerd zijn. Voorts moet worden voorzien in regelmatig persoonlijk overleg, waarin de kennis en ervaring van alle partijen kan worden ingebracht en ook worden benut. Dit stelt eisen aan de bereidheid van mensen met verschillende achtergronden om kennis en ervaring te delen. Ook zullen mensen bereid moeten zijn om zich te verdiepen in de problemen van anderen.

Al doende leren vraagt om een andere benadering dan het afrekenen op geleverde prestaties. Allereerst vraagt het om een toekomstgerichte houding en voorts om een klimaat waarin fouten mogelijk zijn. De traditionele prestatiemeetsystemen zetten geleverde prestaties af tegen van te voren vastgestelde normen en meten afwijkingen van deze normen. Deze systemen veronderstellen stabiliteit en rekenen mensen af op afwijkingen. Samenwerking onder onzekere omstandigheden vraagt om flexibiliteit. om het aanpassen aan nieuwe situaties. Voor dergelijke situaties zijn traditionele prestatiemeetsystemen niet geschik1. Moderne prestatiemeetsystemen als de Balanced Scorecard zijn in principe beter uitgerust voor 
horizontale relaties, omdat deze toekomstgericht zijn, ook niet-financiële informatie bevatten, rekening houden met meer subjectieve aspecten en gericht zijn op relaties tussen de verschillende aspecten. Een top-down-gebruik van deze systemen maakt ze evenwel minder geschikt voor horizontale relaties. Leren wordt bevorderd door betrokkenheid van de desbetreffende partijen bij het opzetten van prestatiemeetsystemen.

MACS berusten op een negatief mensbeeld: mensen moeten worden aangespoord om zich in te spannen, mensen streven het eigen belang na en moeten worden gemotiveerd om rekening te houden met anderen. Uit de beschrijving van de praktijkvoorbeelden komt naar voren dat het bestaan en verder ontwikkelen van vertrouwen tussen de partijen essentieel is voor het voortbestaan van een langdurige horizontale relatie. Het ontwikkelen van vertrouwen veronderstelt een positiever mensbeeld dan waar MACS van uitgaan. Deze tegenstelling is ook terug te vinden in verschillende theoretische benaderingen. Zo veronderstelt de transactiekostentheorie (zie o.a. Williamson, 1979, 1985, 1986, 1996), dat mensen zich in bepaalde omstandigheden opportunistisch kunnen gedragen. Voor het aangaan en afwikkelen van transacties kunnen zodanige beheersingsstructuren worden gekozen, dat de kans op opportunistisch gedrag zo gering mogelijk wordt gemaakt. De meest geschikte beheersingsstructuur is afhankelijk van de aard van de volgende drie factoren: onzekerheid, gespecialiseerdheid van de investeringen en frequentie en volume van de transacties. Door het kiezen van de meest geschikte beheersingsstructuur worden de transactiekosten verbonden aan transacties tussen partijen zo laag mogelijk. Kijken we daarentegen naar transactionele relaties vanuit het perspectief van de netwerkbenadering (zie o.a. Axelsson en Easton, 1992; Johanson en Mattson, 1987) dan staat het begrip vertrouwen veel centraler. De netwerkbenadering benadrukt de relatie en het opbouwen van vertrouwen tussen de partijen. Van der Meer-Kooistra en Vosselman (2000) betogen dat voor het beheersen van horizontale relaties gebruik moet worden gemaakt van de inzichten van beide benaderingen. Hoe onzekerder de omstandigheden waaronder de transactionele relatie tot uitvoer wordt gebracht, hoe meer de relatie afhankelijk wordt van het bestaan van vertrouwen tussen de partijen. In dergelijke onzekere omstandigheden zijn informatie en contractuele regels niet toereikend. Een vergelijking kan worden getrokken met het door Ouchi (1979) onderscheiden clanmechanisme als coördinatiemechanisme, een informeel-sociaal mechanisme dat berust op het bestaan van gemeenschappelijke waarden en normen. Organisaties waarin veel teamwerk voorkomt, waardoor de individuele prestaties moeilijk te meten zijn, gebruiken volgens Ouchi het clanmechanisme voor de onderlinge afstemming tussen de individuen/groepen in een organisatie.

Aandacht dient te worden besteed aan het optreden van conflicten in een horizontale relatie. In een hiërarchische relatie kunnen conflicten worden opgelost door het uitoefenen van het hiërarchische gezag. In een relatie tussen gelijkwaardige partijen kunnen conflicten niet door het inzetten van machtsmiddelen tot een oplossing worden gebracht. Ook in een interne horizontale relatie is het niet raadzaam om conflicten tussen de partijen in eerste instantie door het hogere gezag te laten oplossen. In de organisatiepsychologie bestaat veel aandacht voor conflicten. Conflicten worden niet zonder meer als negatief beoordeeld (De Dreu en Van de Viert, 1997). Tenzij goed beheerst kunnen conflicten tot een oplossing worden gebracht met als uitkomst een meer integratieve samenwerking. Partijen kunnen van conflicten, die kunnen worden beheerst, leren, omdat conflicten leiden tot uitwisseling van informatie, tot inzicht in elkaars posities en tot onderlinge aanpassing. De samenwerking wordt hierdoor verdiept.

\section{Tot besluit}

Uit het voorafgaande kan de conclusie worden getrokken dat er nog veel werk aan de winkel is voor onderzoekers op het gebied van management accounting/control. Er is nog mondjesmaat onderzoek verricht naar de besturing en beheersing van horizontale relaties (zie ook vergelijkbare conclusies van Hopwood, 1996, Otley, 1994 en Shields, 1997). De wetenschap loopt hierin achter bij de praktijk, want binnen en tussen organisaties ontstaan steeds meer horizontale relaties die moeten worden bestuurd. Ook kunnen we vaststellen dat vanuit andere wetenschappelijke gebieden, zoals sociale psychologie en organisatiepsychologie en organisatiekunde, al lang aandacht wordt besteed aan horizontale relaties. 
In het vakgebied management accounting/control is van een vergelijkbare aandacht geen sprake geweest. Het is dan ook aan te bevelen voor het management accounting/control-onderzoek om gebruik te maken van reeds ontwikkelde theoretische concepten gericht op de inrichting en het functioneren van horizontale relaties. In dit verband kan met name worden gewezen op de netwerkbenadering die vooral een sociologische basis heeft, en het onderzoek dat wordt verricht door organisatiepsychologen. Nu organisaties steeds meer ervaring opdoen met horizontale relaties, zou tevens aansluiting bij de praktijk moeten worden gezocht. Ook de praktijk heeft baat bij een grondige reflectie van het functionerell van horizontale relaties.

\section{I T E R A T U U R}

Axelsson, B. en G. Easton, (1992), Industrial networks: a new view of reality, Londen, Routledge.

De Dreu, C.K.W. en E. van de Vliert (eds), (1997), Using conflict in organizations, Londen, Sage.

Easton, G. (1989), Industrial networks: A review, 5th IMP conference, pp. 161-182.

Galbraith, J.R., (1973), Designing complex organizations, Reading, Mass., Addison-Wesley.

Galbraith, J.R., (1977), Organization design, Reading, Mass., Addison-Wesley.

Groffen, W. H., (1963), Horizontaal organiseren, Alphen aan den Rijn, Samsom

Hakansson, H. en J. Johanson, (1988), Formal and informal cooperation strategies in international industrial networks, in: Contractor F.J. en P. Lorange (Eds), Cooperative strategies in international business, Lexington, Mass.: Lexington Books, pp. 369-379.

Helden, G.J. van, J. van der Meer-Kooistra en R.W. Scapens, (1999), Coordination of internal transactions at Hoogovens Steel, SOM Research Report 99A16.

Hopwood, A.G., (1996), Looking across rather than up and down: on the need to explore the lateral processing of information, Accounting, Organizations and Society, 21, pp. 589-560.

Johanson, J. en Mattson, L.G., (1987), Interorganisational relations in industrial systems: a network approach compared with the transaction cost approach, International Studies of Management and Organization, 17, pp. 34-48. Katz, D en R.L. Kahn, (1978), The social psychology of organizations, New York, John Wiley.

Lawrence, P.R. en J.W. Lorch, (1967), Organization and environment: managing differentiation and integration, Boston, Division of Research, Graduate School of Business and Administration, Harvard University.

Leavitt, H.J., (1951), Some effects of certain communication patterns on group performance, Journal of abnormal and social psychology, 46, pp. 38-50

Marginson, D.E.W. (1999), Beyond the budgetary control system: towards a two-tiered process of management control, Management Accounting Research, 10, pp. 203 230.

Martin, H.H., (1997), Contracting out maintenance, Journal of Quality in Maintenance Engineering, 3, pp. 81-90.

Meer-Kooistra, J. van der en E.C.J. Vosselman, (2000), Management control of interfirm transactional relationships: the case of industrial renovation and maintenance, Accounting, Organizations and Society, nog te verschijnen.

Mintzberg, H., (1983), Structures in five, Englewood Cliffs, Prentice Hall

Otley, D., (1994), Management control in contemporary organizations,: towards a wider framework, Management Accounting Research, 5, pp. 289-299.

Ouchi, W.G., (1979), A conceptual framework for the design of organizational control mechanisms, Management Science, 25, pp. 833-848.

Pascale, R, M., Millemann en L. Gioja, (1997), Changing the way we change, Harvard Business Review, nov./dec., pp. 127-139.

Porter, M.E., (1985), Competitive advantage, New York, The Free Press

Sako, M., (1992), Prices, quality and trust: interfirm relationships in Britain and Japan, Cambridge, Cambridge University Press.

Scott, T.W. en P. Tiessen, (1999), Performance measurement and managerial teams, Accounting, Organizations and Society, 24, pp. 263-285

Shank, J.K. en V. Govindarajan, (1993), Strategic cost management, New York, The Free Press.

Shields, M.D., (1997), Research in management accounting by North Americans in the 1990, Journal of Management Accounting Research, vol. 9, pp. 3-61.

Thompson, J., (1967), Organizations in action, New York, McGraw-Hill.

Williamson, O.E., (1979), Transaction cost economics: The governance of contractual relations, Journal of Law and Economics, 22, pp. 233-261

Williamson, O.E., (1985), The economic institutions of capitalism: Firms, markets and relational contracting, New York: Free Press.

Williamson, O.E., (1986), Economic organization: Firms, markets and policy control, Brighton: Wheatsheaf Books.

Williamson, O.E., (1996), The Mechanisms of Governance, Oxford: Oxford University Press. 